\title{
ASEAN's Search for Neutrality in the South China Sea
}

\author{
Ralf Emmers
}

\begin{abstract}
This article seeks to make a contribution to the existing literature on the South China Sea issue by focusing on the impact of regional institutions on conflict management and resolution as well as the limits these institutions face when seeking to de-escalate disputes. The Association of Southeast Asian Nations (ASEAN) has attempted to preserve its neutrality and unity over sovereignty disputes and has focused on the establishment of a conflict management mechanism with China-the Code of Conduct for the South China Sea. However, ASEAN's efforts have been undermined by an escalation of the situation in the disputed waters and by rising China-U.S. competition in the region. The article concludes by discussing various scenarios regarding the future of ASEAN's South China Sea policy.
\end{abstract}

Keywords ASEAN, South China Sea, neutrality, unity, China, United States

\section{Introduction}

The South China Sea is a major area of dispute between Brunei, China, Malaysia, the Philippines, Taiwan, and Vietnam and the issue plays a destabilizing role in the international relations of Asia. The debates over the Spratly and Paracel Islands are affected by the complexity of the overlapping claims and the multilateral nature of the disputes resulting from the number of claimants involved. ${ }^{1}$ The claimant states expect that their control of disputed features, most of which have little worth in themselves, may enable them to gain exclusive jurisdictional rights over the surrounding waters and seabed as well as their living and non-living resources. The question of sovereignty, therefore, remains at the core of the South China Sea disputes. None of the claimants are willing to make concessions on sovereignty, which leaves the territorial issue at an impasse.

The South China Sea question is traditionally examined through the lenses of international law, energy considerations, and the geopolitics of territorial disputes (Beckman 2013; Buszynski 2013; Buszynski and Sazlan 2007; Emmers 
2010a; Owen and Schofield 2012; Segal 1985; Zou 1999). These themes are closely associated with concepts of statehood and sovereignty, the exploration and exploitation of hydrocarbon resources and fisheries, as well as the rise of China and the changing distribution of power in East and Southeast Asia. Circumstances pertaining to the South China Sea conflict are also examined in the context of domestic politics and popular nationalist sentiments. Therefore, the issue is predominantly framed through national perspectives and a realist understanding of power and interests. Among the claimants, China attracts the most attention, especially on the issue of whether Beijing is more likely to resolve its territorial disputes with others through diplomacy or through the use of force (Fravel 2011; Goldstein 2011; Kaplan 2011).

This article seeks to make a contribution to the existing literature on the South China Sea issue by discussing the matter through a different lens. It adopts an institutional perceptive and focuses on the impact of regional institutions on conflict management and resolution as well as the limits they face when seeking to de-escalate disputes. The focus is on how the Association of Southeast Asian Nations (ASEAN), established in Bangkok in August 1967, has sought to peacefully manage the territorial disputes involving four of its ten members, as well as China and Taiwan, while seeking to preserve its diplomatic neutrality on the sovereignty issue. Achieving some form of neutrality has been a long-term objective of the Association since its adoption of the Zone of Peace, Freedom and Neutrality (ZOPFAN) in Kuala Lumpur in November 1971, and the Southeast Asia Nuclear Weapon-Free Zone (SEANWFZ) introduced in Bangkok in December 1995 (ASEAN 1971; ASEAN 1995). Neutrality is here understood to be a call for regional autonomy and the avoidance of partiality and divisions at the ASEAN level while steering clear from the legal obligations associated with the concept of neutralization.

The Southeast Asian claimant states (Brunei, Malaysia, the Philippines, and Vietnam) do not want to discuss their respective sovereignty claims in the South China Sea under the auspices of their regional body, nor does ASEAN as an international institution want to play such a mediating role. Instead, the Association seeks to preserve its neutrality on the sovereignty disputes and to focus on establishing a conflict management mechanism that would include all the ten ASEAN members plus China, first through the implementation of a Declaration on the Conduct of Parties in the South China Sea (DOC) and eventually through the negotiation of a binding Code of Conduct (COC) for the South China Sea. In that sense, the Association has tried to set aside the problem of sovereign jurisdiction and to focus instead on conflict avoidance and management in an attempt to de-escalate the conflicts.

In recent years ASEAN neutrality has been challenged by an escalation of the situation in the disputed waters and more broadly by rising China-U.S. competition in light of renewed Chinese assertiveness and the U.S. rebalance 
to Asia. The South China Sea issue was more manageable in 2013 as compared to previous years, with the significant exception of the ongoing deterioration of relations between China and the Philippines. At the bilateral level, Chinese President Xi Jinping and Premier Li Keqiang visited Brunei, Indonesia, Malaysia, Thailand, and Vietnam in October 2013, while skipping the Philippines due to Manila's decision to seek international arbitration over China's expansive claims under the United Nations Law of the Sea Convention (UNCLOS). At the multilateral level, the decision made at the ASEAN-China Post Ministerial Conference, in July 2013, to start consultations on a COC was a step in the right direction. Still, progress is expected to be slow and remains uncertain at this stage.

Overall, the possibility of ASEAN being split over the South China Sea issue cannot be ruled out, given the diversity of national perspectives in Southeast Asia and China's deepening ties with some individual member states making them more inclined to endorse Beijing's preferences. If this were to happen, it would undermine the foundations of ASEAN's neutrality as well as the relevance of the ASEAN-led institutions in the wider Asia Pacific, such as the ASEAN Regional Forum (ARF), the East Asia Summit (EAS), and the ASEAN Defense Ministerial Meeting Plus (ADMM-Plus).

\section{ASEAN Diplomacy and the South China Sea}

Since the early 1990s the ASEAN members have sought to establish a code of conduct for the South China Sea based on the principles codified in the Treaty of Amity and Cooperation (TAC) and facilitated by ASEAN's informal style of diplomacy (Buszynski 2003; Wiessmann 2010). Adopted in 1976 at the first summit of the ASEAN heads of state and government, the TAC is the central component of the institution's conflict management model, as it provides its member states with a norm-based and informal code of conduct meant to help regulate regional interstate relations and avoid rather than resolve existing or potential disputes (ASEAN 1976). The TAC enumerates a set of international principles well-known in the study of international relations as they are found in the United Nations Charter signed in June 1945. Among others, the TAC refers to the following principles: non-interference in the internal affairs of other states, respect for the independence and sovereignty of all nations, peaceful settlement of disputes, and non-use of force (ASEAN 1976). The TAC also establishes the High Council, which is a dispute resolution mechanism that proposes techniques of mediation and consultation. Yet, the member states have never invoked the High Council in ASEAN's 47-year history.

In addition to the UN principles included in the TAC of 1976, ASEAN's model of conflict management and avoidance has also been influenced by an 
informal style of diplomacy. Known as the "ASEAN Way" and distinct to the Association, this process of interaction helps the members relate with each other and to reach, but also avoid, common decisions. It is defined by a series of features that include informality, quiet diplomacy, dialogue, self-restraint, solidarity, and consensus building (Haacke 2003).

ASEAN has sought, since the early 1990 s, to peacefully manage the South China Sea issue by engaging China. The latter initially refused to take part due to its own attempt to frame the South China Sea as a bilateral rather than a multilateral issue. Beijing refused, for example, to sign the first ASEAN Declaration on the South China Sea adopted in Manila in July 1992 (ASEAN 1992). China has gradually changed its position, however, and since the late 1990s it has adopted, at least rhetorically, ASEAN's norms and principles as well as its style of informal diplomacy. It has done so to strengthen its economic and diplomatic ties with the ASEAN nations as well as to soften its image in Southeast Asia. China's openness to the Southeast Asian diplomatic style was illustrated by its signing of the DOC, in November 2002, and by becoming the first nonASEAN state to ratify the TAC, in October 2003.

The DOC embodies ASEAN's model of conflict management. The ten Southeast Asian states and China stated, in 2002, their respect for the principles of the UN Charter, UNCLOS, the TAC, and the Five Principles of Peaceful Coexistence. Taiwan was not included in the DOC negotiations as Beijing insists that it is part of China and therefore in no position to act as a separate claimant party. The parties agreed to resolve their territorial disputes by peaceful means, "without resorting to the threat or use of force, through friendly consultations and negotiations by sovereign states directly concerned, in accordance with universally recognized principles of international law" (ASEAN 2002). In addition, they pledged to practice self-restraint in activities that could escalate disputes, and to deepen their efforts to "build trust and confidence between and among them" (ASEAN 2002). The DOC formally rejected the use of force in the South China Sea and attempted to mitigate the sovereignty disputes by highlighting the importance of shared principles and the establishment of common norms of behavior.

Many questions remain regarding the relevance and effectiveness of the 2002 Declaration. Tonnesson $(2003,56)$ reminds us that the document "is simply a political statement." For example, it cannot prevent or resolve incidents involving fishing rights in the South China Sea that often provoke strong domestic responses and raise nationalistic sentiments. Significantly, when it was first adopted in November 2002, the DOC was viewed as an interim accord as well as a first step toward further cooperation. The ASEAN member states and China were therefore expected to continue working on the eventual adoption of a binding code of conduct.

Nevertheless, little progress has been made toward the implementation of 
the DOC as well as the eventual negotiation of a binding COC (Storey 2012). This is the case despite the establishment, in 2004, of the ASEAN-China Joint Working Group on the Implementation of the DOC that has led to various activities held over the years to achieve these two specific objectives (ASEAN 2004). Emanating from the Joint Working Group, the new Guidelines for the Implementation of the DOC in the South China Sea were signed by China and the ASEAN countries in July 2011 (ASEAN 2011). Yet, the guidelines were mostly perceived as nonspecific and therefore rather unhelpful with regard to the eventual implementation of the DOC. Furthermore, November 2012, the tenth anniversary of the signing of the DOC, was regarded as a provisional deadline for the completion of a code of conduct for the South China Sea. Instead, the parties involved failed to even start the negotiations for the COC by that point, as China declared that the time was not yet ripe to do so (Storey 2013).

Some tentative progress was finally made in 2013. In April of that year Beijing proposed to organize a special meeting involving the foreign ministers from the ASEAN countries and China to hasten progress on the COC. Moreover, at the 8th meeting of the Joint Working Group for Implementation of the DOC, held in Bangkok in May 2013, China and the ASEAN countries agreed to implement the declaration and promote the 2011 Guidelines. Perhaps most significantly, Beijing and the ASEAN states agreed, in July 2013 in Brunei, to start formal consultations on a COC in September of that year. At a High-Level Forum held in Bangkok on August 2, 2013, Chinese Foreign Minister Wang Yi called for dialogue and the joint development of resources in the South China Sea. The need to prevent a further escalation of the sovereignty disputes in the South China Sea was expressed again at the Special ASEAN-China Foreign Ministers' Meeting in Beijing and at the second ADMM-Plus meeting in Brunei, both held in August 2013 (Straits Times 2013). The first consultations on a COC were eventually held at the 9th ASEAN-China Joint Working Group Meeting on the Implementation of the DOC, held in Suzhou in September 2013 (Thayer 2013; Economist 2013). Chinese Premier Li Keqiang called for peace and cooperation in the South China Sea at the ASEAN-China Summit held in Brunei in October 2013 (Global Times 2013). Finally, officials from ASEAN and China met again, in March 2014, to discuss the South China Sea issue and consult on a COC (Economist 2014).

The signing of a legally binding code of conduct would certainly help in building trust and confidence among the claimants and in setting up a conflict management mechanism to lower the risk of conflict in the South China Sea. It is worth repeating, however, that Taiwan as a claimant party has not been included in the diplomatic process. It is also not yet clear whether China is serious about negotiating a binding code of conduct or is simply buying time to delay the discussions. In August 2013, Chinese Foreign Minister Wang Yi indicated that the consultations would be based on the principles of consensus and non-interference by external parties. Thayer argues that Wang therefore 
signaled China's readiness to veto proposals it did not support and to counter "the influence of the Philippines (and possibly Vietnam) in shaping ASEAN's position on the COC" (Thayer 2013, 4).

\section{Challenges to ASEAN Neutrality in the South China Sea}

\section{Escalation of Tension}

The escalation of the South China Sea disputes in recent years has undermined the prospect for conflict management as well as challenged the neutrality of ASEAN (Bateman 2010; Buszynski 2013; Emmers 2010b). The maritime Southeast Asian nations are concerned over the rapidly growing asymmetry of naval power in the South China Sea to the advantage of China. Of great significance is the buildup of China's Southern Fleet, as its geographical zone of operation is the semi-enclosed sea. The People's Liberation Army Navy (PLAN) has also built an underground nuclear submarine base near Sanya on Hainan Island, significantly increasing China's strategic presence in the disputed waters (Straits Times 2008). The other claimant states are concerned that China's rising naval power, especially its increased submarine capability, could one day be used to enforce its territorial claims through military might. The Philippines and Vietnam have responded by strengthening their own naval capabilities as well as building up the military structures on the features they separately occupy in the Spratlys. Vietnam has purchased six Kilo class submarines from Russia while the Philippines has reinforced its defence alliance with Washington through the holding of additional joint naval exercises. Still, their respective naval capabilities are no match for the PLAN and its naval power projection in the South China Sea.

In addition to the naval arms buildup, there has been an increase, since 2010, in the number of incidents involving the claimant countries in the South China Sea. These have included the repeated arrest of fishermen by national coast guards, the cutting of cables, and the harassment of survey vessels. The most significant incident occurred in April 2012 and involved Chinese and Philippine vessels in a standoff at Scarborough Shoal in the South China Sea (Perlez 2012). The shoal, located to the west of the Philippine island of Luzon, is disputed by both Beijing and Manila. A Philippine navy ship attempted to arrest Chinese fishermen after it had discovered several Chinese fishing vessels anchored at the shoal and allegedly involved in poaching and illegal fishing. However, two Chinese maritime surveillance ships intervened and interrupted the Philippine operation, eventually preventing the arrest from occurring. The incident at Scarborough Shoal led to further friction between Philippine and Chinese maritime vessels and eventually caused severe diplomatic and economic tension between Beijing and Manila that lasted for months (Economist 2012; Valencia 
2012a). In addition to a war of words involving senior Chinese and Philippine officials, Beijing exerted economic pressure on Manila-short of imposing direct economic sanctions-by curbing the import of Philippine bananas through the introduction of tighter entry rules into China (West 2012).

The Scarborough Shoal incident directly impacted the ASEAN diplomatic process and openly questioned ASEAN's neutral stance on the South China Sea disputes. The impact was first observed at the ASEAN Ministerial Meeting (AMM) held in Phnom Penh in July 2012. Acting as the ASEAN chair, Cambodia sought to appease Beijing by taking on board its concerns and minimizing the internationalization of the South China Sea issue. It should be noted that Cambodia is a close economic partner of China and dependent on its financial aid to sustain Cambodia's economic development. For the first time in its 45year history, ASEAN failed to issue a joint communiqué due to differences over the South China Sea question (Puy 2012). The Philippines had asked for the Scarborough Shoal incident to be mentioned in the draft communiqué, but Cambodia refused to include a reference on the grounds that the sovereignty disputes with China are bilateral and not multilateral in nature. China does not want the disputes to be discussed at international forums, especially when they involve external parties, preferring instead to negotiate bilaterally with the Southeast Asian claimants.

Indonesia undertook a round of shuttle diplomacy, in July 2012, to salvage the situation and restore ASEAN's credibility. Deriving from the Indonesian initiative, Cambodia eventually released an ASEAN statement a week after the failed AMM that listed six basic principles on the South China Sea. These included the exercise of self-restraint and the non-use of force, an early adoption of a code of conduct, as well as the peaceful resolution of conflicts in accordance with UNCLOS. A lack of consensus among the member states prevented the adoption of a joint communiqué, however. Indonesia also circulated a "zero draft COC" during an ASEAN informal meeting held on the sidelines of the opening of the 67th regular session of the United Nations General Assembly, in September 2012, in an attempt to find a regional solution to the South China Sea question (Ririhena 2012).

Most recently, China blocked two Philippine vessels carrying supplies to a few marines stationed aboard the Sierra Madre, a rusting Philippine ship grounded on the Second Thomas Shoal since 1999. Located within the 200 nautical mile exclusive economic zone (EEZ) of the Philippines, the shoal is claimed both by Beijing and Manila. China blocked the supply boats in March 2014 claiming that they were transporting building materials meant to carry out construction work on the shoal in breach of the 2002 DOC (Economist 2014). In response, the Philippines stated that the shoal is part of its continental shelf and is therefore "entitled to exercise sovereignty rights and jurisdiction in the area without the permission of other states" (cited in BBC News 2014). 


\section{China-U.S. Competition}

Beyond an immediate escalation of tension in the disputed waters, increased China-U.S. competition in Asia has also complicated the peaceful management of the South China Sea disputes and challenged ASEAN neutrality on the issue. China and the United States are competing for regional influence and their rivalry has negatively impacted the overall climate of relations. The Southeast Asian states have continued to rely on their hedging strategy of not choosing between their immediate security guarantor (the United States) and their long-term economic partner (China). This strategy makes perfect sense from a Southeast Asian perspective, as being forced to choose would ultimately undermine ASEAN's neutrality on the South China Sea and other issues.

The United States is a non-claimant party in the South China Sea conflict and it limits its interest to the preservation of the freedom of navigation, which includes the free passage of commercial shipping and warships as well as the conduct of military surveillance operations. It officially supports no claims in the area, although it has recently challenged China's historical claims as defined by China's "nine-dash line" that covers most of the South China Sea (Keck 2014). The testimony by Assistant Secretary Daniel Russel before the House Committee on Foreign Affairs in February 2014 was particularly significant in this regard. In an apparent shift in U.S. policy on the South China Sea, he publicly stated that any "use of the 'nine-dash line' by China to claim maritime rights not based on claimed land features would be inconsistent with international law" (Russel 2014).

The United States has in recent years become concerned over the rise of the Chinese navy and whether Beijing might be ready to challenge the freedom of navigation principle in the disputed waters of the South China Sea. Its concern was significantly raised as a result of the so-called "Impeccable incident" of March 2009. This involved the harassment of the ocean surveillance vessel USNS Impeccable by Chinese navy and civilian patrol vessels south of Hainan Island (Tyson 2009). The United States argued that the activities of the Impeccable were legitimate under the freedom of navigation principle as formulated under UNCLOS, while China claimed that the surveillance vessel was involved in an operation in its EEZ that first required its official consent.

In addition to bilateral frictions with China over the issue, the United States has also raised the South China Sea disputes at multilateral forums. In July 2010, then-U.S. Secretary of State Hilary Clinton declared at the ARF that the United States has a national interest in the freedom of navigation in the South China Sea. Her comments angered China, as they were perceived as a form of external interference. China had managed until 2010 to keep the South China Sea off the ARF agenda (Storey 2010). Yet, besides the United States, 11 other ARF participants mentioned the disputes in their statements at the meeting in July 2010, possibly having been emboldened by the U.S. position on the matter. 
Clinton decided to again mention the South China Sea issue at the next ARF meeting held in Bali in July 2011.

The increased attention given by the United States to the South China Sea issue needs to be placed in the wider strategic context of the Obama administration's decision, in its first term in office, to refocus its diplomacy and military forces toward Asia, as part of a larger "pivot" or rebalancing strategy (see Clinton 2011). The latter has included a deepening of American military ties with the Philippines, the rotational deployment of 2,500 U.S. Marines in Darwin, Australia, and the deployment of up to four of its littoral combat ships (LCS) in Singapore. Still, budget cuts and domestic constraints in the United States have complicated the implementation of the pivot to Asia. For example, President Obama had to cancel his scheduled trip to attend the Asia Pacific Economic Forum (APEC) summit and the EAS, organized respectively in Bali and Brunei in October 2013, due to a U.S. federal government shutdown.

China has been critical of the U.S. rebalancing strategy in Asia. It views the pivot as an attempt by Washington to contain China's rise by allocating more military might to the region and by strengthening U.S. bilateral alliances under its "hub and spoke" alliance system set up by the San Francisco conference of September 1951. China is especially concerned that the United States is interfering in the South China Sea issue which it views as bilateral disputes with Brunei, Malaysia, the Philippines, and Vietnam. The Chinese Defense Ministry published a White Paper in April 2013 that indirectly referred to the United States and its pivot to Asia. The report stated that "[S]ome country has strengthened its Asia-Pacific military alliances, expanded its military presence in the region, and frequently makes the situation tenser" (cited in Perlez and Buckley 2013). Beijing views any attempt at internationalizing and legalizing the South China Sea disputes as a threat to its own national interests in the region.

In particular, China perceives the Philippine policy on the South China Sea to have been emboldened by the U.S. pivot to Asia. For example, it regarded the Philippine position during the Scarborough Shoal incident in 2012 to have been influenced by the United States, especially after Washington openly criticized, in a press statement released in August 2012, China's decision to upgrade the administrative level of Sansha City and establish a new military garrison in the Paracels (CNN 2012). Beijing had set up an army garrison a month before on Woody Island, which is located more than 200 nautical miles southeast of Hainan Island. In response to the press statement issued by the U.S. Department of State, China declared that Washington was sending wrong signals to the region and undermining efforts to promote peace and stability in the South China Sea. Beijing saw a similar connection to the U.S. pivot when the Philippines decided to challenge China's jurisdictional claims in the South China Sea by filing a statement of claim, on January 22, 2013, before the special arbitral tribunal under UNCLOS, Annex VII. China quickly dismissed the Philippine challenge 
and rejected the statement of claim on February 19, 2013 (Thayer 2013). The Philippines made its final submission to the UN tribunal on March 30, 2014. The tribunal has yet to determine whether it has jurisdiction, although Beijing has already decided to ignore the legal step undertaken by Manila.

China and the United States disagree over where the South China Sea question should be discussed and how it should be resolved. Washington wants to raise the issue at international forums (the ARF, EAS, and the ADMM-Plus) and it seeks a solution in accordance with international law-although it has not itself ratified UNCLOS. China regards the U.S. position as highly problematic, as China favors an exclusive dialogue with ASEAN on the South China Sea and bilateral negotiations with the claimant parties involved rather than international arbitration at the International Court of Justice in The Hague, or at the International Tribunal for the Law of the Sea in Hamburg.

The great power rivalry has already divided the ASEAN states to some extent (Bateman 2012). The Philippines in particular has reacted positively to the U.S. pivot due to its growing concerns over China's assertiveness in the South China Sea. The rebalance has provided Manila, and to a lesser extent Hanoi, with additional diplomatic and strategic leverage in their sovereignty disputes with China (Valencia 2012b). In contrast, feeling less threatened by China, Malaysia and Brunei have been more worried about the pivoting of U.S. military forces to Southeast Asia and the mistrust it has generated in China.

\section{ASEAN Neutrality in the Coming Years}

The territorial disputes over the South China Sea are likely to remain a key security flashpoint in Asia in the coming years. The start of consultations on a COC is a step in the right direction, but it is unlikely that a binding document will be completed between ASEAN and China anytime soon. Moreover, while China has repeatedly declared that it does not want to see an escalation of tension in the disputed waters, the rise in influence of the PLAN on the sovereignty issue could result in more frequent small-scale skirmishes between China and the other claimant states. Indeed, the PLAN is advocating a more assertive stance on the disputes in comparison to the Chinese Ministry of Foreign Affairs (Buszynski and Sazlan 2007). Fisheries incidents that escalate into diplomatic tension should also be expected to recur frequently in the years to come. The situation in the South China Sea is therefore unlikely to improve in the short-to-medium term.

Significantly, ASEAN's own disunity on the South China Sea has been highlighted in recent years. This has resulted from a lack of consensus among the members not only on how to manage the South China Sea disputes but also on the larger question of how to deal with a rapidly rising China. The Southeast Asian states have differing economic and diplomatic relationships with their 
giant neighbor and contrasting views on its potential threat to regional peace and stability. In addition, some ASEAN nations have territorial claims in the South China Sea that overlap with China while others are not involved in the sovereignty disputes. These critical differences have made it much harder to achieve a common position and to establish a binding code of conduct acceptable to China as well as to all the Southeast Asian states.

The Southeast Asian states will continue to have varying threat perceptions on the rise of China and what it means for the stability of the region in the coming years. At one end of the spectrum will be Vietnam and the Philippines which have vast overlapping claims with China over the South China Sea and have indicated their readiness to internationalize and legalize the issue. Both countries have repeatedly raised the South China Sea issue at international forums. Moreover, Hanoi passed the Sea Law of Vietnam, in June 2012, which angered Beijing as it reasserted the country's sovereignty over the Paracel and Spratly Islands, while Manila has sought international arbitration under UNCLOS. In contrast, Brunei and Malaysia are less likely to take an active approach and instead may be more reluctant to play up their disputes with China. In particular, they seem less keen to internationalize and legalize any disputes.

Among the non-claimant states, Singapore has remained a neutral party in the sovereignty disputes and has limited its interest to the preservation of the freedom of navigation. Yet, the city-state will continue to closely monitor events in the South China Sea in light of its vital economic and strategic interests in the sea lanes of communication that cross the disputed areas. In the case of Indonesia and Thailand, Jakarta will continue to demonstrate the most active interest among the non-claimants in seeking to find a regional solution to the issue, while Bangkok's position will arguably be more careful as it hopes to deepen its friendly ties with China. Cambodia, Myanmar, and Laos are expected to remain ambivalent as non-claimant states and to hold a less active interest in the South China Sea. These countries will seek to expand their close economic and diplomatic ties with China and they will therefore have little incentive to internationalize the territorial issue.

Whether ASEAN can preserve its neutrality over the South China Sea will partly depend on the policies adopted by China. The Southeast Asian states would welcome a Chinese diplomatic engagement with ASEAN that remains comprehensive and sustained in its approach. Regardless of the South China Sea disputes, China's involvement in the ASEAN-led regional institutions has been effective in partially transforming its image in Southeast Asia. China has been an active participant in the ARF and also in the ASEAN Plus Three (APT), the EAS, and the ADMM-Plus. Chinese engagement with Southeast Asia was illustrated, in October 2013, by the successful visits to the region by President Xi Jinping and Premier Li Keqiang as part of the APEC Summit and EAS, as well as by their bilateral visits to five Southeast Asian countries (Ho and Pitakdumrongkit 
2013). As mentioned above, the Philippines was not included in their itineraries, however, and thus given the "cold shoulder" due to its submission to the arbitral tribunal. If China and ASEAN continue to broaden and strengthen their relationship, it may be easier for the Association to peacefully manage the South China Sea issue as the deepening interdependence between the parties involved could help in de-escalating the situation in the disputed waters.

In contrast, a more assertive China would create more uncertainties in Southeast Asia over the role that Beijing wants to play in the region and further complicate the establishment of institutional mechanisms meant to address the South China Sea issue. Such an assertive policy could involve China imposing an Air Defense Identification Zone (ADIZ) over the South China Sea similar to the zone Beijing introduced in the East China Sea in November 2012. The geographical area that such a zone might cover remains highly speculative at this point, as it could vary from being confined to an area south of Hainan Island to one that includes the Spratly Islands and most of the South China Sea. A Chinese ADIZ over the South China Sea would certainly undermine bilateral relations with most ASEAN members, especially the maritime states, and negatively impact negotiation of a COC in the long term. Overall, a more assertive Chinese policy would constitute an even greater challenge to ASEAN neutrality. It could potentially split the Association, with the continental non-claimant states preferring to bandwagon with China on the one hand and the maritime Southeast Asian states relying on their defense ties with the United States on the other.

A middle-ground scenario is more likely, however. This would involve a situation where China's dual policy of engagement and assertiveness toward Southeast Asia would not be mutually exclusive but instead complementary and mutually reinforcing. In other words, China could further engage ASEAN diplomatically and economically despite the persistence of its assertive policy toward the South China Sea. Beijing might practice such a dual strategy, especially if it considers that its national interests are being threatened in the disputed waters. Therefore, in the coming years China is likely to conduct an active diplomacy toward some claimant states (Malaysia and Brunei) and nonclaimants (Thailand, Cambodia, Laos, and Myanmar) while seeking to isolate other Southeast Asian nations (the Philippines and, to a lesser extent, Vietnam).

Finally, in such a middle-ground scenario, the United States and China would continue to compete for influence in Southeast Asia. The ASEAN countries would most likely stick to a hedging strategy when it comes to managing their relations with the two great powers. Still, the ability of ASEAN to remain neutral on the South China Sea and other issues could be severely undermined if relations between Washington and Beijing were to deteriorate significantly. Under such circumstances, the two great powers might force the Southeast Asian states to choose sides. The eventual outcome of such a worst-case scenario is unclear at this stage, although it should be noted that China's influence over some 
Southeast Asian nations is rising and as a result its ability to impose some form of compliance on these countries is also increasing.

\section{Conclusion}

Events in recent years have challenged ASEAN diplomacy on the South China Sea issue. The regional body does not support any claims over the disputed waters and seeks instead to establish a conflict management mechanism through the negotiation of a binding code of conduct to lower the risk of conflict. Its neutrality has been undermined, however, by an escalation of the situation in the semi-enclosed sea and by rising China-U.S. competition in Asia. The more tension in the disputed waters and the more rivalry in great power relations, the greater the challenge posed to the Association. The incidents at Scarborough Shoal and the Second Thomas Shoal, in 2012 and 2014 respectively, have illustrated the deterioration of China-Philippine relations over the South China Sea issue. Likewise, the deepening competition between China and the United States has further complicated ASEAN's efforts in conflict management and the preservation of its neutrality.

Despite these difficult circumstances, Brunei still managed to start a consultative process on a code of conduct under the umbrella of the DOC implementation during its ASEAN chairmanship in 2013. All the parties agreed in July of that year to hold consultations-rather than negotiations-on how to move forward on the COC process. The chairmanship of Brunei was therefore perceived as having provided new momentum to ASEAN diplomacy after the controversial Cambodian chairmanship the year before and to have reestablished, at least up to a point, its unity on the South China Sea issue. For its part, China seems to have moved away from its resistance to at least consult on the eventual negotiation of a code of conduct with the ASEAN states.

Nevertheless, China and the ASEAN members do not share similar perspectives on the way forward. While the Southeast Asian states would prefer to conclude a COC as quickly as possible, Beijing wants to see the full implementation of the DOC before the formal COC negotiations officially begin. This is precisely why the ASEAN-China meeting held in Suzhou in September 2013 referred to a consultation on a COC within the framework of the DOC implementation rather than to the start of formal negotiations. China, therefore, supports a step-by-step approach whereby the conclusion of a COC is perceived as a long-term rather than an immediate objective. This significant gap in terms of how Beijing and the Southeast Asian capitals view future negotiations serves as a reminder of the long way to go before a binding code of conduct for the South China Sea can be achieved.

How will ASEAN neutrality with regard to the South China Sea issue be 
affected in the coming years? The possibility of ASEAN being split over the South China Sea issue is real in the medium term, given the diversity of national perspectives across the member states, as well as China's rising regional influence resulting from its expanding military and economic capabilities. This is especially true as the distribution of military and economic power between China and Southeast Asia is likely to continue to shift in Beijing's favor in the coming years. If a split over the South China Sea were to happen, it would undermine ASEAN's neutrality as well as the relevance of the ASEAN-centric institutions as part of the emerging security architecture in the Asia Pacific. Such an outcome would have profound repercussions for Southeast Asia and its regional institution, both diplomatically and economically. The member states need to take this risk seriously, as a regional split would severely undermine ASEAN's role in regional affairs. It is therefore in ASEAN's interest to ensure that great power rivalry is managed through institutional mechanisms and that ASEAN's neutrality over the South China Sea is preserved.

\section{Notes}

An earlier version of this paper was presented at the 5th International Workshop on "The South China Sea: Cooperation for Regional Security and Development," organized by the Diplomatic Academy of Vietnam, Hanoi, November 11-12, 2013. The author wishes to thank the Editor of the Asian Journal of Peacebuilding and the anonymous reviewer for their insightful comments and suggestions.

1. The various claimants call the islands and geographic features in the South China Sea by different names. This article acknowledges this fact and uses the English names of the disputed islands and features in order to maintain neutrality. It therefore refers to the Paracel Islands, Scarborough Shoal, Second Thomas Shoal, the Spratly Islands, and Woody Island.

\section{References}

ASEAN. 1971. Zone of Peace, Freedom and Neutrality Declaration. Kuala Lumpur, Malaysia, November 27.

ASEAN. 1976. Treaty of Amity and Co-operation in South-East Asia. Bali, Indonesia, February 24.

ASEAN. 1992. ASEAN Declaration on the South China Sea. Manila, the Philippines, July 22.

ASEAN. 1995. Treaty on the Southeast Asia Nuclear Weapon-Free Zone. Bangkok, Thailand, December 15.

ASEAN. 2002. Declaration on the Conduct of Parties in the South China Sea. Phnom Penh, Cambodia, November 4. 
ASEAN. 2004. Terms of Reference of the ASEAN-China Joint Working Group on the Implementation of the Declaration on the Conduct of Parties in the South China Sea. Kuala Lumpur, Malaysia, December 7.

ASEAN. 2011. Guidelines for the Implementation of the Declaration on the Conduct of Parties in the South China Sea. Bali, Indonesia, July 20.

Baruah, Darshana. 2014. "South China Sea: Beijing's 'Salami Slicing' Strategy.” RSIS Commentaries, March 21. Singapore: S. Rajaratnam School of International Studies.

Bateman, Sam. 2010. "The South China Sea: When the Elephants Dance." RSIS Commentaries, August 16. Singapore: S. Rajaratnam School of International Studies.

Bateman, Sam. 2012. "Increasing Competition in the South China Sea: Need for a New Game Plan." RSIS Commentaries, August 21. Singapore: S. Rajaratnam School of International Studies.

BBC News. 2014. "Philippines Lodges Protest over China Ship Blockade." March 11.

Beckman, Robert. 2013. "The UN Convention on the Law of the Sea and the Maritime Disputes in the South China Sea." The American Journal of International Law 107 (1): 142-163.

Buszynski, Leszek. 2003. "ASEAN, the Declaration on Conduct, and the South China Sea." Contemporary Southeast Asia 25 (3): 343-362.

Buszynski, Leszek. 2013. "The South China Sea Maritime Dispute: Legality, Power, and Conflict Prevention." Asian Journal of Peacebuilding 1 (1): 39-63.

Buszynski, Leszek, and Iskandar Sazlan. 2007. "Maritime Claims and Energy Cooperation in the South China Sea." Contemporary Southeast Asia 29 (1): 143-171.

Clinton, Hillary. 2011. "America's Pacific Century." Foreign Policy, October 11.

CNN. 2012. "China blasts U.S. for sending 'Wrong Message' on South China Sea Disputes." August 6.

Economist. 2012. "Shoal Mates: America's Navy Riles China in Its Backyard.” April 28.

Economist. 2013. "Flaws in the Diamond." September 21.

Economist. 2014. “The Pressure on the Sierra Madre." March 22.

Emmers, Ralf. 2010a. Geopolitics and Maritime Territorial Disputes in East Asia. Routledge: London.

Emmers, Ralf. 2010b. "The Changing Distribution of Power in the South China Sea: Implications for Conflict Management and Avoidance." Political Science 62 (2): 118131.

Fravel, M. Taylor. 2011. "China's Strategy in the South China Sea." Contemporary Southeast Asia 33 (3): 292-319.

Global Times. 2013. "Li Calls for Peaceful South China Sea." October 10.

Goldstein, Lyle. 2011. "Chinese Naval Strategy in the South China Sea: An Abundance of Noise and Smoke, but Little Fire." Contemporary Southeast Asia 33 (3): 320-347.

Haacke, Jurgen. 2003. ASEAN's Diplomatic and Security Culture: Origins, Development and Prospects. London: RoutledgeCurzon.

Ho, Benjamin, and Kaewkamol Pitakdumrongkit. 2013. "Beijing's ASEAN Embrace: Making Hay while the Sun Shines." RSIS Commentaries, October 9. Singapore: S. Rajaratnam School of International Studies.

Kaplan, Robert D. 2011. "The South China Sea is the Future of Conflict." Foreign Policy, August 15.

Keck, Zachary. 2014. “US Challenges China’s Nine-Dash Line Claim.” The Diplomat, 
February 12.

Owen, Nick A., and Clive H. Schofield. 2012. "Disputed South China Sea Hydrocarbons in Perspective." Marine Policy 36 (3): 809-822.

Perlez, Jane. 2012. "Beijing Exhibiting New Assertiveness in South China Sea." The New York Times, May 31.

Perlez, Jane, and C. Buckley. 2013. “China Paper Suggests US is Making Asia 'Tenser.” International Herald Tribune, April 17.

Puy, Kea. 2012. "S. China Sea Row Forces ASEAN to Forego Communique for 1st Time in 45 Years." Kyodo News, July 13.

Ririhena, Yohanna. 2012. "RI Circulates Draft Code of Conduct on South China Sea." Jakarta Post, September 29.

Russel, Daniel R. 2014. Assistant Secretary, Bureau of East Asian and Pacific Affairs, Testimony before the House Committee on Foreign Affairs Subcommittee on Asia and the Pacific. Washington, D.C., February 5.

Santos, Matikas. 2012. "Poaching Triggers Scarborough Stand-Off." Philippine Daily Inquirer, April 11.

Segal, Gerald. 1985. Defending China. Oxford: Oxford University Press.

Storey, Ian. 2010. "Power Play in S. China Sea Stirs up Tension." Straits Times, July 27.

Storey, Ian. 2012. "The Institutionalization of ASEAN-China Relations: Managing the South China Sea Dispute." In ASEAN and the Institutionalization of East Asia, ed. Ralf Emmers. London: Routledge, 138-152.

Storey, Ian. 2013. "China Runs Rings around ASEAN." Wall Street Journal, October 2.

Straits Times. 2008. "China 'Building Underground Nuclear Sub Base." May 3.

Straits Times. 2013. “Editorial: Keeping Seas Calm in the Region.” September 2.

Thayer, Carlyle A. 2013. "New Commitment to a Code of Conduct in the South China Sea?” NBR Commentary. Seattle, WA: The National Bureau of Asian Research, October 9 .

Tonnesson, Stein. 2003. "Sino-Vietnamese Rapprochement and the South China Sea Irritant.” Security Dialogue 34 (1): 55-70.

Tyson, Ann Scott. 2009. "Navy Sends Destroyer to Protect Surveillance Ship after Incident in South China Sea." Washington Post, March 13.

Valencia, Mark J. 2012a. "Current Spat May Be a Sign of Future Tensions." Straits Times, May 14.

Valencia, Mark J. 2012b. “High-Stakes Drama: The South China Sea Disputes.” Global Asia 7 (3): 56-73.

West, Kesha. 2012. "Banana Crisis Blamed on Philippines-China Dispute". Australia Network News, June 29.

Wiessmann, Mikael. 2010. "The South China Sea Conflict and Sino-ASEAN Relations: A Study in Conflict Prevention and Peace Building." Asian Perspective 34 (2): 35-69.

Zou, Keyuan. 1999. “The Chinese Traditional Maritime Boundary Line in the South China Sea and its Legal Consequences for the Resolution of the Dispute over the Spratly Islands." International Journal of Marine and Coastal Law 14 (1): 27-55. 
Ralf Emmers is Associate Professor at the S. Rajaratnam School of International Studies (RSIS), Nanyang Technological University (NTU), Singapore. His research interests cover security studies, international institutions in the Asia-Pacific, and the security and international politics of Southeast Asia. He is the author of Resource Management and Contested Territories in East Asia (Palgrave Macmillan, 2013), Geopolitics and Maritime Territorial Disputes in East Asia (Routledge, 2010), and Cooperative Security and the Balance of Power in ASEAN and the ARF (RoutledgeCurzon, 2003). E-mail: isremmers@ntu.edu.sg 
